\title{
FORMULATION, OPTIMIZATION, AND CHARACTERIZATION OF TRANSDERMAL DRUG DELIVERY SYSTEMS CONTAINING EPLERENONE
}

\author{
RAMESH SHINDE ${ }^{1}$, MALARKODI VELRAJ ${ }^{*}$ \\ 1,2*Department of Pharmaceutical Sciences, School of Pharmaceutical Sciences, Vels Institute of Science, Technology and Advanced \\ Studies, Chennai, Tamil Nadu, India, Chennai, Tamilnadu, India \\ *Email: malarkodisanna@gmail.com
}

Received: 04 Aug 2021, Revised and Accepted: 14 Oct 2021

\section{ABSTRACT}

Objective: The proposed work was aimed at optimization, formulation, and characterization of transdermal patches of eplerenone for efficient transdermal delivery of the drug

Methods: The $\log \mathrm{p}$ estimation of eplerenone is 1.34, it was closer to standard worth. Log P value in a range of 1 to 4 indicates higher permeation through the skin. FTIIR study was carried out individually for drug, each polymer, and finished product (Patches) compared eplerenone and FTIR spectra of pure drug and polymer. The calibration curve of eplerenone in Phosphate buffer $\mathrm{pH} 6.8$ was analyzed.

Results: The selected range of eplerenone was found to be linear. A regression coefficient $\left(\mathrm{R}^{2}\right)$ at $245 \mathrm{~nm}$ was found to be 0.994 . Drug content outcomes additionally discovered uniform in all clusters in a range of $97 \%$ to $98 \%$, that batches arranged with ERS 100 show great mechanical properties contrast with different polymers however helpless glue properties. The flatness of $4 \mathrm{~cm}^{2}$ patches ranges from $348 \pm 0.087 \mathrm{mg}$ to $387 \pm 0.527 \mathrm{mg}$. skin irritation it was produced irritation with negligible erythema following $10 \mathrm{~d}$ and unequivocal erythema, promptly obvious edema was produced following $12 \mathrm{~d}$.

Conclusion: These after-effects of the in vivo skin irritation study recommended that advanced batch S9 doesn't show any kind of significant disturbance on rodent skin for as long as $14 \mathrm{~d}$ and it was securely utilized around $24 \mathrm{~h}$. the optimized batch S9 drug was constantly discharged through the Wistar rodent skin up to $16 \mathrm{hr}$ and the delivery design was like an in vitro dissolution profile of the market product.

Keywords: TDDS, Eplerenone, ERS 100, In vivo skin irritation study

(C) 2022 The Authors. Published by Innovare Academic Sciences Pvt Ltd. This is an open-access article under the CC BY license (https://creativecommons.org/licenses/by/4.0/) DOI: https://dx.doi.org/10.22159/ijap.2022v14i1.42827. Journal homepage: https://innovareacademics.in/journals/index.php/ijap

\section{INTRODUCTION}

Skin penetration energy is fundamental to the fruitful improvement of the transdermal restorative framework. Transdermal saturation of medication includes the following advances:-Sorption by layer corneum, Infiltration of medication through the feasible epidermis, Uptake of medication by narrow organization in dermal papillary layer. Transdermal medication conveyance frameworks (TDDS) are measurements structures that include drug transport to feasible epidermal or potentially dermal tissues of the skin for neighborhood restorative impact while an exceptionally significant part of medication is shipped into the foundational blood course. The glue of the transdermal medication conveyance framework [1-5], is basic to the security, viability, and nature of the item. Eplerenone, an aldosterone receptor foe like spironolactone, has been appeared to create supported expansions in plasma renin and serum aldosterone, steady with the hindrance of the negative administrative input of aldosterone on renin emission. The subsequent expanded plasma renin action and aldosterone circling levels don't beat the impacts of eplerenone [6-8]. The proposed work was meant to streamlining the plan and portrayal of transdermal patches of eplerenone for the productive transdermal conveyance of medication in drug framework to improve the antihypertensive impact of eplerenone. Sometimes In vitro transdermal permeation was carried using modified KesharyChein diffusion cells across rat epidermis [9].

\section{MATERIALS AND METHODS}

The pure drug eplerenone was purchased from Chemo Pvt. Ltd, Mumbai, Eudragit RS 100, Eudragit RL 100, Propylene glycol, PEG 400 were purchased from Chemdyes corporation, Rajkot, India, HPMC K15M from Loba Chemie Pvt. Ltd., Mumbai, India. Ethanol was obtained from Shree Chalthan Vibhag Khandudyog Sahkari Mandli Ltd, Surat.

Pre-formulation studies

Pre-formulation testing of the dynamic substances gives helpful data. It might be important to consider the physicochemical qualities of dynamic substance in the plan comparable to the proposed dose structure and course of the organization [9]. Despite the fact that the vast majority of the expository and recognizable proof boundaries was at that point performed by Chemo Pvt. Ltd. Mumbai (M. H.) India who give the identification test of eplerenone pure drug for research work [10].

\section{Determination of $\lambda_{\max }$}

For assurance of $\lambda_{\max }$ stock solution of eplerenone (conc. $1000 \mu \mathrm{g} / \mathrm{ml}$ ) in methanol were readied [10]. $1 \mathrm{ml}$ of the readied stock arrangement was additionally weakened to $100 \mathrm{ml}$. Coming about arrangements were examined in the range of 400 to $200 \mathrm{~nm}$ utilizing methanol as a clear with the assistance of a UV-visible spectrophotometer [11]. Normal triplicate readings were taken.

\section{Calibration curve of eplerenone in $\mathrm{pH}-6.8$ phosphate buffer}

The above stock arrangement filtered for the most extreme absorbance utilizing UV max of eplerenone in phosphate buffer $\mathrm{pH}$ 6.8 was seen as $245 \mathrm{~nm}[11,12]$. The above stock arrangement $(100$ $\mathrm{g} / \mathrm{ml}$ ) was additionally weakened to get focus in the range of 10-50 $\mathrm{g} / \mathrm{ml}$. The absorbance of every arrangement was estimated utilizing a UV-Visible double beam spectrophotometer by putting reference standards of a particular medium. The standard bend produced for a whole range of conc. and the tests acted in triplicate.

\section{The partition coefficient of the drug}

Log $P[13,14]$, was estimated utilizing a separating funnel by shaking equivalent volumes of oil and watery stage.

\section{Melting point identification}

The Melting purpose of eplerenone was resolved to utilize the open capillary technique [15].

\section{Permeation study of the pure drug}

The in vitro drug discharge looks were finished by using Franz dispersion cell. The rodent skin of the stomach part was managed 
and hair was emptied and propped between the receptor and provider compartments. The receptor compartment was stacked up with $15 \mathrm{ml}$ of scattering medium (Phosphate cushion $\mathrm{pH}$ 7.4) through examining port taking thought to oust all the air bubbles. The substances were blended at $500 \mathrm{rpm}$ by distantly decided, Teflon covered minimal appealing touch to keep them all around mixed. Decisively measured $5 \mathrm{mg}$ of eplerenone was separated in phosphate cushion $\mathrm{pH} 7.4$ and set in receptor compartment [16]. At proper stretches of time, aliquots $(3 \mathrm{ml})$ were assembled and sensible weaken the aliquot with phosphate cushion and absorbance was assessing at $245 \mathrm{~nm}$ using a twofold shaft UV spectrophotometer (Shimadzu SL-1800).

\section{Preliminary trial batches for selection of permeation enhancers}

The skin flux of eplerenone got without penetration enhancer was $75.25 \mu \mathrm{g} / \mathrm{cm}^{2} / \mathrm{h}$ and it was not adequate to gain focus on flux [17], for keeping up the helpful convergence of medication up to foreordained period.
Dose for the formulation of transdermal matrix patch of eplerenone

Diameter of Petri Plate $=6.8 \mathrm{~cm}$,

Area of Petri plate $=3.14 \times(3.4)^{2}=36.29 \mathrm{~cm}^{2}$

Area of patch $=2 \mathrm{~cm} \times 2 \mathrm{~cm}=4 \mathrm{~cm}^{2}$ the total No. of patches in each Petri-dish plate $=$ Area of Petri plate $/$ Area of patch $=36.29 / 6=6.04$ Now, one patch contains $8 \mathrm{mg}$ of drug then 6.04 patches contain $48.33 \mathrm{mg}$ of drug $(49 \mathrm{mg})$.

\section{Preliminary trial batches for selection of polymers}

Primer preliminary trial batch ERS1 to H3, arranged by solvent evaporation method for choice of different fix framing polymers and their concentration. In which groups ERS1 to ERS3 were getting ready for the choice of Eudragit RS 100 (ERS 100) conc., ERL1 to ERL3 were set up for the determination of Eudragit RL 100 (ER) conc., $\mathrm{H} 1$ to $\mathrm{H} 3$ was set up for the choice of various evaluations and concentrations of HPMC K15M [17-19].

Table 2: Preliminary trial batches of polymers

\begin{tabular}{|c|c|c|c|c|c|c|c|c|c|}
\hline Ingredient(s)(mg) & ERS1 & ERS2 & ERS3 & ERL1 & ERL2 & ERL3 & H1 & $\mathbf{H} 2$ & H3 \\
\hline Eplerenone & 49 & 49 & 49 & 49 & 49 & 49 & 49 & 49 & 49 \\
\hline ERS100 & 100 & 200 & 300 & - & - & - & - & - & - \\
\hline ERL100 & - & - & - & 100 & 200 & 300 & - & - & - \\
\hline HPMC K15 & - & - & - & - & - & - & 100 & 200 & 300 \\
\hline
\end{tabular}

Statistical optimization of the formulation variables using $3^{2}$ full factorial experimental design

Fundamental preliminary batches were arranged and assessed for the determination of different centralizations of polymers, plasticizers, and permeation enhancers. After-effects of fundamental preliminary clusters proposed that batches arranged with ERS and ERL 100 [20] show great mechanical properties however, helpless adhesive properties. $3^{2}$ full factorial structures were select from Design Expert programming 9.0 for the advancement of conclusive detailing. This plan included three dependent variables (Y1, Y2, and $\mathrm{Y} 3$ ) or more referenced two independent variables (X1 and X2). The needy factors Y1 was rigidity (BS) of arranged patches, Y2 was drug release in the introductory first hour (Q1h) and Y3 was medicated discharge following $16 \mathrm{~h}(\mathrm{Q} 16 \mathrm{~h})[16,19,20]$.

Method of preparation of transdermal patch of batches S1-S9 using $3^{2}$ full factorial designs

The transdermal patches containing eplerenone were readied utilizing various proportions of ERS100/ERL 100 and HPMC K15M. The polymer's focus was a change with this proportion of 250:50, $225: 75$, and 200:100 [16-18], by keeping the consistent load of polymer $300 \mathrm{mg}$ with proportion (2:1) of ERS100/ERL 100: HPMC $\mathrm{K} 15 \mathrm{M}$, then permitted to grow for two hrs in water.

Table 3: Formulation of eplerenone loading factorial design batches S1 to S9

\begin{tabular}{|c|c|c|c|c|c|c|c|c|c|}
\hline Batch code & S1 & S2 & S3 & S4 & S5 & S6 & S7 & S8 & S9 \\
\hline Eplerenone (mg) & 49 & 49 & 49 & 49 & 49 & 49 & 49 & 49 & 49 \\
\hline ERS/ERL 100 (mg) & 250 & 250 & 250 & 225 & 225 & 225 & 200 & 200 & 200 \\
\hline HPMC K15 (mg) & 50 & 50 & 50 & 75 & 75 & 75 & 100 & 100 & 100 \\
\hline Water $(\mathrm{mL})$ & 11 & 11 & 11 & 11 & 11 & 11 & 11 & 11 & 11 \\
\hline Ethanol (mL) & 10 & 10 & 10 & 10 & 10 & 10 & 10 & 10 & 10 \\
\hline PG (\%) w/w & 20 & 20 & 20 & 20 & 20 & 20 & 20 & 20 & 20 \\
\hline MO $(\%) \mathrm{w} / \mathrm{w}$ & 10 & 20 & 30 & 10 & 20 & 30 & 10 & 20 & 30 \\
\hline
\end{tabular}

\section{Evaluation of TDDS}

\section{The thickness of the patch}

The thickness of the prescription stacked fix was assessed in different concentrations by using a micrometer screw measure and chooses the typical thickness and standard deviation for the equal to ensure the thickness of the prepared fix $[10,33]$.

\section{Drug content}

The measure of medication present in the fix was dictated by dissolving the fix in $100 \mathrm{ml}$ of phosphate cradle $\mathrm{pH}$ 6.8. By then the plan is to be isolated through a channel medium and analyze the medicine using (UV technique) at $245 \mathrm{~nm}$.

\section{Percentage moisture content}

The prepared patches were weighed exclusively and to be kept in a desiccators containing melded calcium chloride at room temperature for $24 \mathrm{~h}$. After $24 \mathrm{~h}$ the movies are to be rechecked and decide the rate dampness content from the beneath referenced formula.

$$
\text { Percentage mois ture content }=\frac{\text { Initial weight- Final weight }}{\text { Final weight }} \times 100
$$

\section{Percentage moisture uptake}

The gauged patches were kept in a desiccator at room temperature for $24 \mathrm{~h}$ containing a soaked arrangement of potassium chloride [34] to keep up $84 \% \mathrm{RH}$. After $24 \mathrm{~h}$ the movies are to be rechecked and decide the rate dampness take-up from the beneath referenced equation.

Percentage moisture uptake $=\frac{\text { Final weight- Initial weight }}{\text { Initial weight }} \times 100$

\section{Weight uniformity}

The prepared patches were dried on the stove at $60^{\circ}$ for $24 \mathrm{~h}$ prior to testing. A predetermined territory of fix is to be cut in various pieces of the fix and say something computerized balance [20,34]. 
The normal weight and standard deviation esteems are to be determined from the individual loads.

\section{Water vapor permeability}

Glass vials of $5 \mathrm{ml}$ limit were washed altogether and dried to a consistent load on a stove. About $1 \mathrm{~g}$ of melded Calcium chloride was taken in the vials and the polymer films were fixed over the edge with the assistance of a sticky tape. At that point, the vials were gauged and put away in a mugginess chamber at $85 \% \mathrm{RH}$ condition [35] for a time of $24 \mathrm{~h}$. The vials were eliminated and weighed at different time stretches like $3,6,12,18$, and $24 \mathrm{~h}$ to note down the weight pick up.

\section{Folding endurance}

A portion of the explicit territory was cut equitably and consistently collapsed at a similar spot till it broke. The occasions the film could be collapsed at a similar spot without breaking gave the estimation of the collapsing perseverance [36].

\section{Percentage elongation break test}

The rate stretching break was controlled by noticing the length not long before the breakpoint, the rate extension can be resolved from the beneath referenced formula.

$$
\text { Elongation percentage }=\frac{\mathrm{L} 1-\mathrm{L} 2}{\mathrm{~L} 2} \times 100
$$

Where L1is the final length of each strip and L2 is the initial length of each strip

\section{Weight variation}

The appraisal of weight variety was performed by weighing independently drug stacked five patches of each plan on an advanced equilibrium. The normal loads were determined and the standard deviation from the normal loads was estimated.

\section{Tensile strength}

The tensile strength of the readied patches was measure by a secretly gathered instrument. The elasticity of the fix was assessed using a secretly assembled instrument. In which one side of fix fixed into the iron screens and another side related with the paper holder where the catch was inserted [37]. One string was joined with this catch, which ignored the pulley and a little dish attached to the furthest edge for holding the weight. Little pointer was annexed to the string, which goes over the scale appended on the base plate. For assessment of rigidity, the fix was pulled and stacks were step by step added to the dish to assemble the pulling power till the fix was broken. Full-scale loads needed to break the fix considered as a force, putting the assessment of intensity into the condition flexibility was measured.

\section{Flatness}

A transdermal patch should have a smooth surface and should not stifle with time. To survey this property evenness study was performed [32]. In this, study one portion of the fix cut from the center and two from each side. The length of each strip was assessed and assortment long notes down. Zero percent narrowing will be proportionate to $100 \%$ levelness.

$$
\text { Percentage constriction }=\frac{11-12}{11} * 100
$$

\section{pH}

The patch was set in a beaker and was soaked with $10 \mathrm{ml}$ of distilled water and saved for $30 \mathrm{~min}$. The $\mathrm{pH}$ was measure subsequent to bringing the terminal of the $\mathrm{pH}$ meter in contact with the outside of the plan and permit equilibrates for 2 to $3 \min [34,36]$.

\section{In vitro drug release studies}

The in vitro discharge study was finished with the semi-permeable film using Franz dissemination cell [36]. The chamber contains two chambers, the supplier and the receptor compartment. The supplier compartment was open at the top and was introduced to the air. The temperature was kept up at $37 \pm 0.5{ }^{\circ} \mathrm{C}$ and the receptor compartment was outfitted with a testing port. The scattering medium used was phosphate uphold ( $\mathrm{pH}$ 7.4).

\section{Ex-vivo diffusion study of final optimized matrix patch}

For this examination recently yielded with ether Wistar rat skin was gathered, first of hair from the skin was expelled then skin wash with phosphate buffer solution lastly secured with aluminum foil and put away at 3 to $5^{\circ} \mathrm{C}$ in a cooler for permeation study $[19,37]$.

\section{In vivo skin irritation study of transdermal patch}

Skin irritation study intended to distinguish disturbance under states of maximal pressure and during the appraisal of transdermal drug products. A study was performed on 18 Wistar rats for $14 \mathrm{~d}$. Irritation study $[17,20,38]$ performed on three groups (each group has 6 rodents), to be specific Group 1 was doled out as a control group apply with characteristic skin irritation, $0.9 \% \mathrm{w} / \mathrm{v}$ saline; Group 2 apply with placebo patch, Group 3 apply with last optimized batch. Patch applied on the posterior of smooth skin of rodents for $23 \pm 1 \mathrm{~h}$ up to $14 \mathrm{~d}$ to a similar skin site.

\section{RESULTS AND DISCUSSION}

Table 4: Solubility study of eplerenone

\begin{tabular}{lll}
\hline Medium solubility & Solubility & Calculated value \\
\hline Ethanol & Freely soluble & $26 \mu \mathrm{g} / \mathrm{ml}$ \\
Methanol & Soluble & $23.2 \mu \mathrm{g} / \mathrm{ml}$ \\
Chloroform Soluble & Soluble & $18.8 \mu \mathrm{m} / \mathrm{ml}$ \\
Distilled Water & Practically insoluble & $6 \mu \mathrm{g} / \mathrm{ml}$ \\
pH 6.8 Buffer & Soluble & $19 \mu \mathrm{g} / \mathrm{ml}$ \\
\hline
\end{tabular}

The $\log$ p estimation of eplerenone 1.34, it was closer to standard worth. Log P value in a range of 1 to 4 indicates higher permeation through the skin.

\section{Spectra of eplerenone in phosphate buffer pH 6.8}

The standard stock solution was prepared as per the method described in the methodology section and scanned by UV-spectrophotometer. The UV absorption spectrum of eplerenone showed a peak at $245 \mathrm{~nm}$ against blank and the same was used for further analysis.

\section{Preliminary studies of pure drug permeation}

The penetration flux of eplerenone across wistar rodents saw as $51.01 \mu \mathrm{g} / \mathrm{cm} 2 / \mathrm{h}$. The diffusion coefficient was $0.0116 \times 10-8 \mathrm{~cm}^{2} / \mathrm{h}$ and penetrability coefficient was $0.45 \times 10^{-2} / \mathrm{cm} / \mathrm{h}$. The acquired information of medication release study proposed that pure medication having adequate permeation through the skin; however, the got flux was insufficient to keep up consistent state plasma conc. of medication all through the treatment [39]. Hence, further improvement in flux accomplishes utilizing fundamental oils as normal permeation enhancers. In this current exploration work fundamental oil to be specific mentha oil (MO), was selected and attempted [40-43]. 


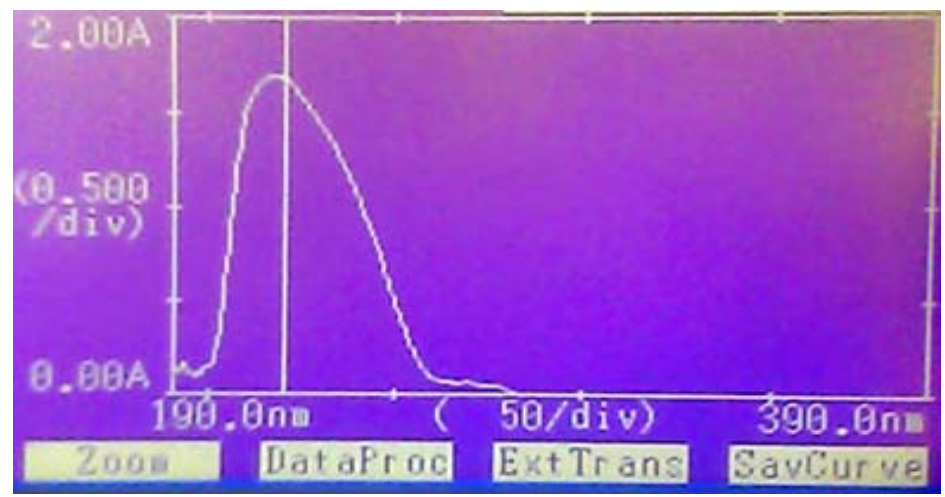

Fig. 1: Spectra of eplerenone in phosphate buffer $\mathrm{pH} 6.8$

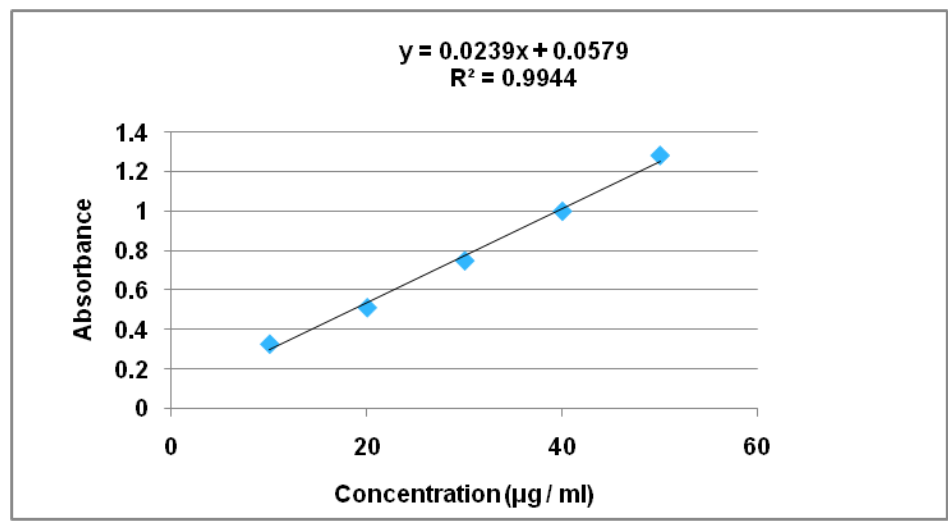

Fig. 2: Calibration curve of eplerenone in phosphate buffer pH 6.8

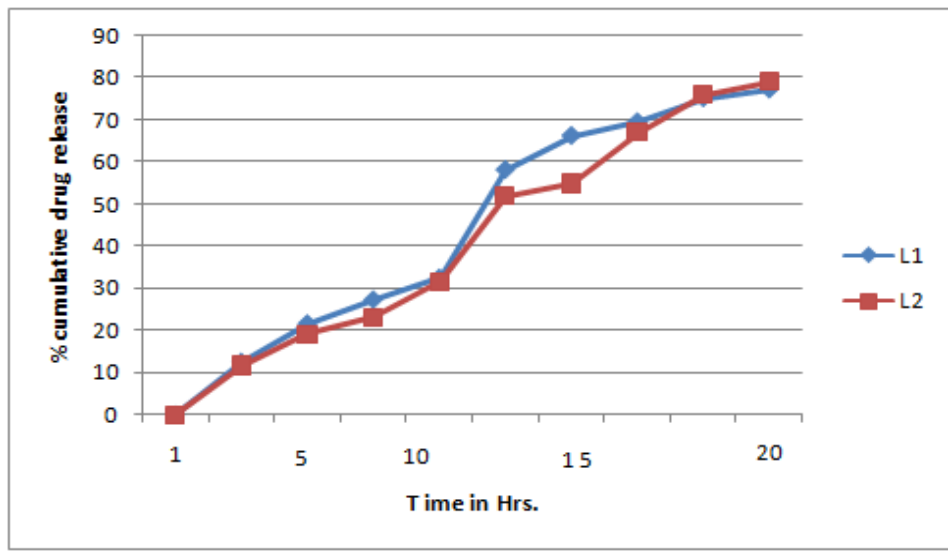

Fig. 3: Comparative drug release profile of batches L1-L2

Table 4: Data of concentrations and absorbance in phosphate buffer pH 6.8

\begin{tabular}{lll}
\hline S. No. & Concentration $(\boldsymbol{\mu g} / \mathbf{m l})$ & Absorbance \\
\hline 1. & 10 & 0.330 \\
2. & 20 & 0.514 \\
3. & 30 & 0.751 \\
4. & 40 & 1.001 \\
5. & 50 & 1.283 \\
\hline
\end{tabular}

Improvement in permeability using permeation enhancers

Gotten consequences of bunches PEC1 to PEC7 for development in penetration with various centralization of chose essential oils as enhancers uncovered that permeation increment with increment in the convergence of basic oils since they improve the diffusion of medication particles through the various layers of skin by parceling into the lipid cell of layer corneum. This was obvious from the aftereffects of eplerenone permeation at $16 \mathrm{~h}$ from PEC2 to PEC7 with MO thus at various groupings of $10 \% \mathrm{w} / \mathrm{w}$ and $20 \% \mathrm{w} / \mathrm{w}$ of the allout weight of dry polymer weight, results appeared in fig. 4 . The higher diffusion was acquired by provided a rising request for basic oil.

\section{Preliminary trial batches for the polymers}

Preliminary trial batches ERS1 to H9 were prepared for the selection of patch forming polymer and its concentration. 


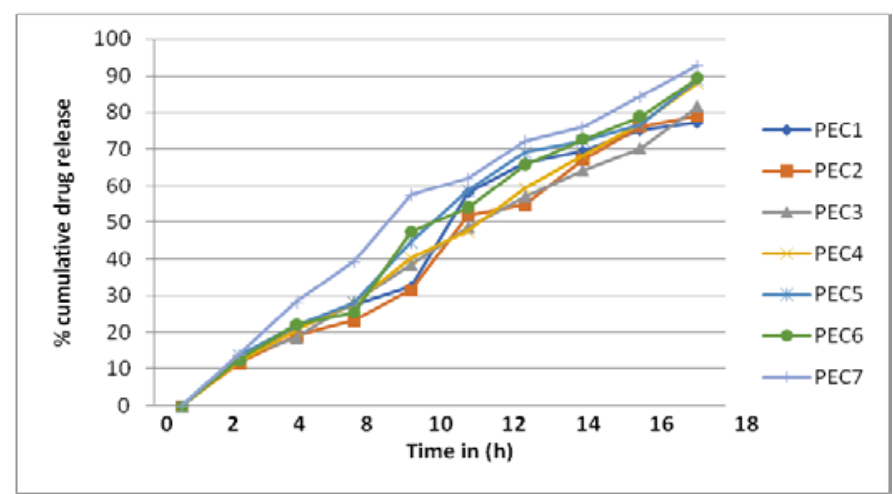

Fig. 4: Comparative drug release profile of batches PEC1 to PEC7

Table 5: Physicochemical parameters of batches ERS1 to ERL3

\begin{tabular}{lllll}
\hline Batch code & Weight variation (mg) & Thickness (mm) & Drug content (\%) & Flatness (\%) \\
\hline ERS1 & $360 \pm 0.732$ & $0.10 \pm 0.11$ & $97.26 \pm 0.21$ & $99.8 \pm 0.22$ \\
ERS2 & $373 \pm 0.516$ & $0.14 \pm 0.22$ & $98.34 \pm 0.87$ & $98.9 \pm 0.23$ \\
ERS3 & $307 \pm 0.527$ & $0.15 \pm 0.12$ & $98.84 \pm 0.80$ & $98.4 \pm 0.24$ \\
ERL1 & $346 \pm 0.087$ & $0.16 \pm 0.23$ & $97.52 \pm 0.40$ & $99.7 \pm 0.26$ \\
ERL2 & $388 \pm 0.527$ & $0.22 \pm 0.24$ & $98.68 \pm 0.49$ & $99.8 \pm 0.27$ \\
ERL3 & $378 \pm 0.320$ & $0.18 \pm 0.21$ & $97.79 \pm 0.52$ & $98.1 \pm 0.17$ \\
\hline
\end{tabular}

(Where $\mathrm{n}=3$, mean $\pm \mathrm{SD}$ )

Table 6: Physicochemical parameters of batches $\mathrm{H1}$ to $\mathrm{H9}$

\begin{tabular}{lllll}
\hline Batch code & Weight variation (mg) & Thickness (mm) & Drug content (\%) & Flatness (\%) \\
\hline H1 & $360 \pm 0.732$ & $0.10 \pm 0.11$ & $97.26 \pm 0.21$ & $99.8 \pm 0.22$ \\
H2 & $373 \pm 0.516$ & $0.14 \pm 0.22$ & $98.34 \pm 0.87$ & $98.9 \pm 0.23$ \\
H3 & $370 \pm 0.527$ & $0.15 \pm 0.12$ & $98.84 \pm 0.80$ & $98.4 \pm 0.24$ \\
H4 & $346 \pm 0.087$ & $0.16 \pm 0.23$ & $97.52 \pm 0.40$ & $99.7 \pm 0.26$ \\
H5 & $388 \pm 0.527$ & $0.22 \pm 0.24$ & $98.68 \pm 0.49$ & $99.8 \pm 0.27$ \\
H6 & $378 \pm 0.320$ & $0.18 \pm 0.21$ & $97.79 \pm 0.52$ & $98.1 \pm 0.17$ \\
H7 & $370 \pm 0.320$ & $0.10 \pm 0.11$ & $97.28 \pm 0.21$ & $93.8 \pm 0.22$ \\
H8 & $353 \pm 0.231$ & $0.11 \pm 0.19$ & $96.84 \pm 0.29$ & $93.1 \pm 0.28$ \\
H9 & $337 \pm 0.253$ & $0.13 \pm 0.21$ & $97.66 \pm 0.24$ & $94.4 \pm 0.24$ \\
\hline
\end{tabular}

Table 7: Physicochemical evaluation of eplerenone loading batches S1 to S9

\begin{tabular}{|c|c|c|c|c|c|}
\hline Batch code & Weight variation (mg) & Thickness (mm) & Folding endurance & \% moisture uptake & \% Moisture loss \\
\hline S1 & $360 \pm 0.732$ & $0.10 \pm 0.11$ & $358 \pm 0.23$ & $1.86 \pm 0.07$ & $2.78 \pm 0.09$ \\
\hline S2 & $373 \pm 0.516$ & $0.14 \pm 0.22$ & $362 \pm 0.21$ & $2.60 \pm 0.06$ & $1.86 \pm 0.08$ \\
\hline S3 & $369 \pm 0.527$ & $0.15 \pm 0.12$ & $354 \pm 0.23$ & $2.50 \pm 0.18$ & $1.98 \pm 0.68$ \\
\hline S4 & $348 \pm 0.087$ & $0.16 \pm 0.23$ & $356 \pm 0.22$ & $2.42 \pm 0.12$ & $2.14 \pm 0.05$ \\
\hline S5 & $387 \pm 0.527$ & $0.19 \pm 0.24$ & $368 \pm 0.21$ & $1.90 \pm 0.30$ & $1.56 \pm 0.59$ \\
\hline S6 & $378 \pm 0.320$ & $0.18 \pm 0.21$ & $346 \pm 0.20$ & $1.80 \pm 0.05$ & $2.26 \pm 0.03$ \\
\hline S7 & $370 \pm 0.320$ & $0.10 \pm 0.11$ & $249 \pm 0.27$ & $1.63 \pm 0.21$ & $2.45 \pm 0.06$ \\
\hline S8 & $353 \pm 0.231$ & $0.11 \pm 0.19$ & $263 \pm 0.29$ & $2.72 \pm 0.05$ & $1.93 \pm 0.02$ \\
\hline S9 & $337 \pm 0.253$ & $0.13 \pm 0.21$ & $254 \pm 0.21$ & $1.98 \pm 0.16$ & $1.80 \pm 0.14$ \\
\hline
\end{tabular}

(Where $\mathrm{n}=3$, mean $\pm \mathrm{SD}$ )

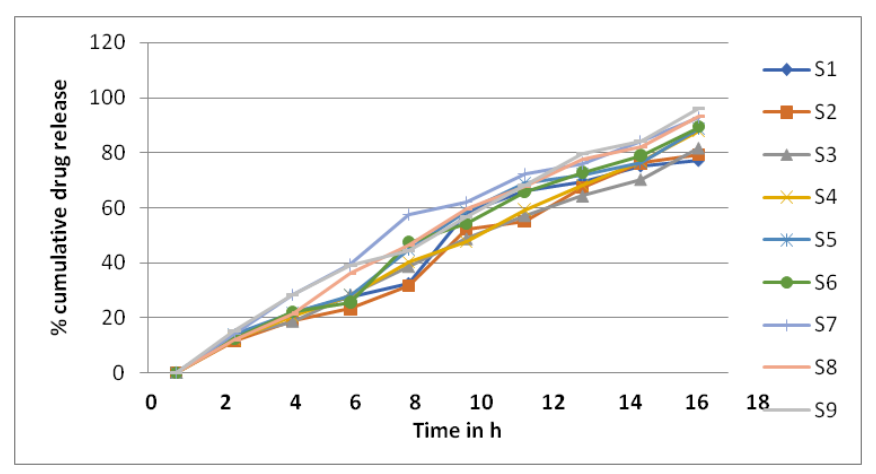

Fig. 6: Comparative drug release profile of batches S1-S9 
Table 8: Results of dependent variables of batches $S 1$ to S9

\begin{tabular}{|c|c|c|c|c|c|}
\hline \multirow{2}{*}{$\begin{array}{l}\text { Batch code } \\
\text { S1 } \\
\end{array}$} & \multicolumn{2}{|c|}{ Code value } & \multicolumn{3}{|c|}{ Dependent variables } \\
\hline & $\mathbf{X 1}$ & $\mathrm{X} 2$ & Y1 & Y2 & Y3 \\
\hline S2 & -1 & -1 & $10.42 \pm 0.23$ & $72.18 \pm 0.22$ & $3.51 \pm 0.01$ \\
\hline S3 & -1 & 0 & $11.36 \pm 0.40$ & $74.56 \pm 0.21$ & $3.62 \pm 0.02$ \\
\hline S4 & -1 & 1 & $12.62 \pm 0.32$ & $76.21 \pm 0.65$ & $3.65 \pm 0.02$ \\
\hline S5 & 0 & -1 & $13.51 \pm 0.12$ & $79.02 \pm 0.50$ & $3.70 \pm 0.03$ \\
\hline S6 & 0 & 0 & $14.26 \pm 0.28$ & $81.03 \pm 0.45$ & $3.75 \pm 0.03$ \\
\hline S7 & 0 & 1 & $15.53 \pm 0.20$ & $83.12 \pm 0.06$ & $3.81 \pm 0.02$ \\
\hline S8 & 1 & -1 & $16.45 \pm 0.63$ & $85.63 \pm 0.41$ & $3.85 \pm 0.01$ \\
\hline \multirow[t]{2}{*}{ S9 } & 1 & 0 & $17.76 \pm 0.03$ & $88.01 \pm 0.72$ & $3.92 \pm 0.04$ \\
\hline & 1 & 1 & $18.22 \pm 0.04$ & $90.22 \pm 0.52$ & $4.98 \pm 0.03$ \\
\hline
\end{tabular}

(Where $\mathrm{n}=3$, mean $\pm \mathrm{SD}$ )

Analysis of variance and model equations for tensile strength of batches $S 1$ to $S 9$

For response surface analysis, a two-way analysis of variance was generated by Design Expert 9.0 software. The Model F-value was more than the tabulated F-value (3.44) which implies that the model is significant, and the higher value of $\mathrm{R}^{2}$ (0.995) indicates good fitting of the model. The polynomial equation derived for the estimation was mention below.

Tensile strength $+3.67+0.44^{*} \mathrm{~A}+0.18 * \mathrm{~B}+0.075^{*} \mathrm{AB}+0.23 * \mathrm{~A} 2-$ $0.020 * \mathrm{~B} 2-----[1]$
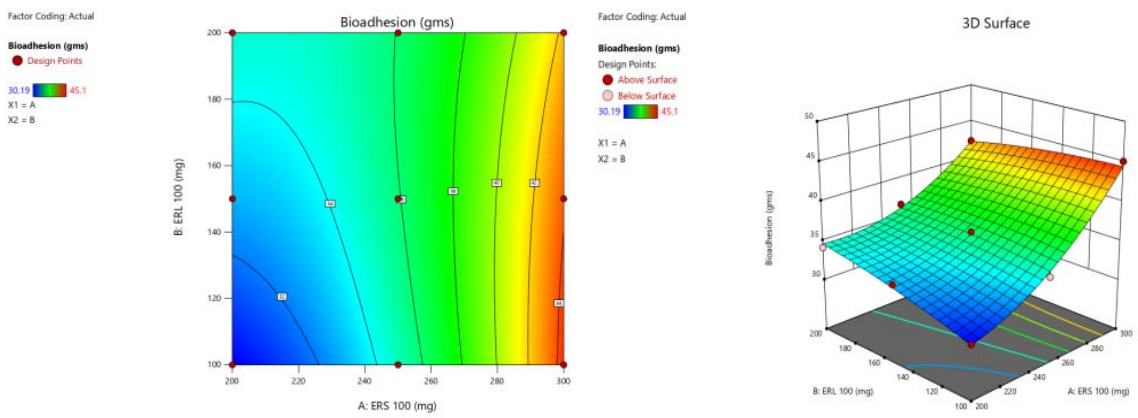

Fig. 7: Counter plot and (B) Response surface plot of the effect of polymer fixed weight ratio and mentha oil on tensile strength of batches s1 to s9

Analysis of variance and model equations for drug released in Q1(h)

For response surface analysis, a two-way analysis of variance was generated by Design Expert 9.0 software. The Model F-value was more than the tabulated F-value (3.56) which implies that the model is significant and the higher value of $\mathrm{R}^{2}(0.998)$ indicates good fitting of the model. The polynomial equation derived for the estimation was mention below $[44,45]$.

$\% \operatorname{CDR}(16 \mathrm{~h})=93.0956+3.63667 * \mathrm{~A}+-1.55667 * \mathrm{~B}+-0.07 *$ $\mathrm{AB}+0.806667 * \mathrm{~A}^{\wedge} 2+-1.08333 * \mathrm{~B}^{\wedge} 2$
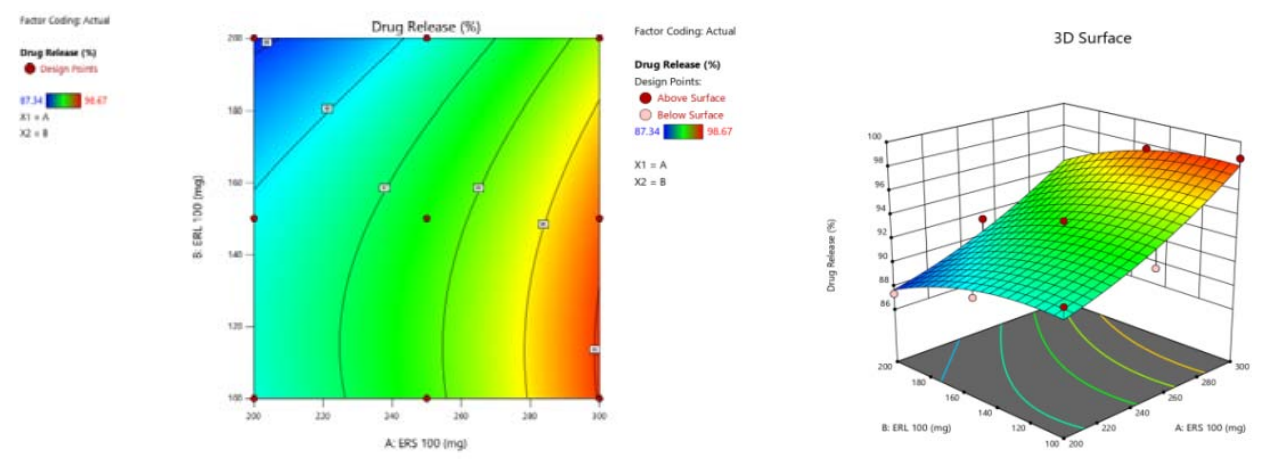

Fig. 8: Counter plot and (B) Response surface plot show the effect of polymer fixed weight ratio and mentha oil on the percent drug released in $1 \mathrm{H}$ from batches S1-S9

Table 9: Kinetic models and regression coefficient

\begin{tabular}{lll}
\hline S. No. & Equation & Regression coefficient \\
\hline 1 & Zero-order & 0.9916 \\
2 & First-order & 0.5425 \\
3 & Higuchi & 0.9752 \\
4 & Korsmeyer-Peppas & 0.9514 \\
5 & Hixson Crowell & 0.6803 \\
\hline
\end{tabular}




\section{In vivo skin irritation study}

The convention clarified in the system part utilized for skin irritation study. Saline solution delivering skin irritation responses contrasted and the disturbance happened after the utilization of Placebo fix as a group 2 and optimized batch (S9) as a group 3. Each group containing six rodents it. Skin irritation was determined on the basis of standards 0 to 7 given in the system part and got.

Table 10: Skin irritation study of group-1(Control group-0.9\% W/V saline)

\begin{tabular}{|c|c|c|c|c|c|c|c|c|c|c|c|c|c|c|c|}
\hline S. No. & Skin irritation symptom & D1 & D2 & D3 & D4 & D5 & D6 & D7 & D8 & D9 & D10 & D11 & D12 & D13 & D14 \\
\hline 1 & 0 & - & - & - & - & - & - & $\mathrm{P}$ & $\mathrm{P}$ & $\mathrm{P}$ & $\mathrm{P}$ & $\mathrm{P}$ & $\mathrm{P}$ & $\mathrm{P}$ & $\mathrm{P}$ \\
\hline 2 & 1 & - & - & - & - & - & - & - & - & - & $\mathrm{P}$ & $\mathrm{P}$ & $\mathrm{P}$ & $\mathrm{P}$ & $\mathrm{P}$ \\
\hline 3 & 2 & - & - & - & - & - & - & - & - & - & - & - & $\mathrm{P}$ & $\mathrm{P}$ & $\mathrm{P}$ \\
\hline 4 & 3 & - & - & - & - & - & - & - & - & - & - & - & - & $\mathrm{P}$ & $\mathrm{P}$ \\
\hline 5 & 4 & - & - & - & - & - & - & - & - & - & - & - & - & - & $\mathrm{P}$ \\
\hline 6 & 5 & - & - & - & - & - & - & - & - & - & - & - & - & - & - \\
\hline 7 & 6 & - & - & - & - & - & - & - & - & - & - & - & - & - & - \\
\hline 8 & 7 & - & - & - & - & - & - & - & - & - & - & - & - & - & - \\
\hline
\end{tabular}

P-Severity of skin injury

Table 11: Skin irritation study of group 2 (Applied with placebo patch)

\begin{tabular}{|c|c|c|c|c|c|c|c|c|c|c|c|c|c|c|c|}
\hline S. No. & Skin irritation symptom & D1 & D2 & D3 & D4 & D5 & D6 & D7 & D8 & D9 & D10 & D11 & D12 & D13 & D14 \\
\hline 1 & 0 & - & - & - & - & - & - & - & - & - & - & $\mathrm{P}$ & $\mathrm{P}$ & $\mathrm{P}$ & $\mathrm{P}$ \\
\hline 2 & 1 & - & - & - & - & - & - & - & - & - & - & - & $\mathrm{P}$ & $P$ & $P$ \\
\hline 3 & 2 & - & - & - & - & - & - & - & - & - & - & - & - & $\mathrm{P}$ & $P$ \\
\hline 4 & 3 & - & - & - & - & - & - & - & - & - & - & - & - & - & - \\
\hline 5 & 4 & - & - & - & - & - & - & - & - & - & - & - & - & - & - \\
\hline 6 & 5 & - & - & - & - & - & - & - & - & - & - & - & - & - & - \\
\hline 7 & 6 & - & - & - & - & - & - & - & - & - & - & - & - & - & - \\
\hline 8 & 7 & - & - & - & - & - & - & - & - & - & - & - & - & - & - \\
\hline
\end{tabular}

Table 12: Skin irritation study of group 3 (Applied with drug batch-S9)

\begin{tabular}{|c|c|c|c|c|c|c|c|c|c|c|c|c|c|c|c|}
\hline S. No. & Skin irritation symptom & D1 & D2 & D3 & D4 & D5 & D6 & D7 & D8 & D9 & D10 & D11 & D12 & D13 & D14 \\
\hline 1 & 0 & - & - & - & - & - & - & - & - & - & - & $\mathrm{P}$ & $\mathrm{P}$ & $\mathrm{P}$ & $\mathrm{P}$ \\
\hline 2 & 1 & - & - & - & - & - & - & - & - & - & - & - & $\mathrm{P}$ & $\mathrm{P}$ & $\mathrm{P}$ \\
\hline 3 & 2 & - & - & - & - & - & - & - & - & - & - & - & - & $\mathrm{P}$ & $\mathrm{P}$ \\
\hline 4 & 3 & - & - & - & - & - & - & - & - & - & - & - & - & - & - \\
\hline 5 & 4 & - & - & - & - & - & - & - & - & - & - & - & - & - & - \\
\hline 6 & 5 & - & - & - & - & - & - & - & - & - & - & - & - & - & - \\
\hline 7 & 6 & - & - & - & - & - & - & - & - & - & - & - & - & - & - \\
\hline 8 & 7 & - & - & - & - & - & - & - & - & - & - & - & - & - & - \\
\hline
\end{tabular}
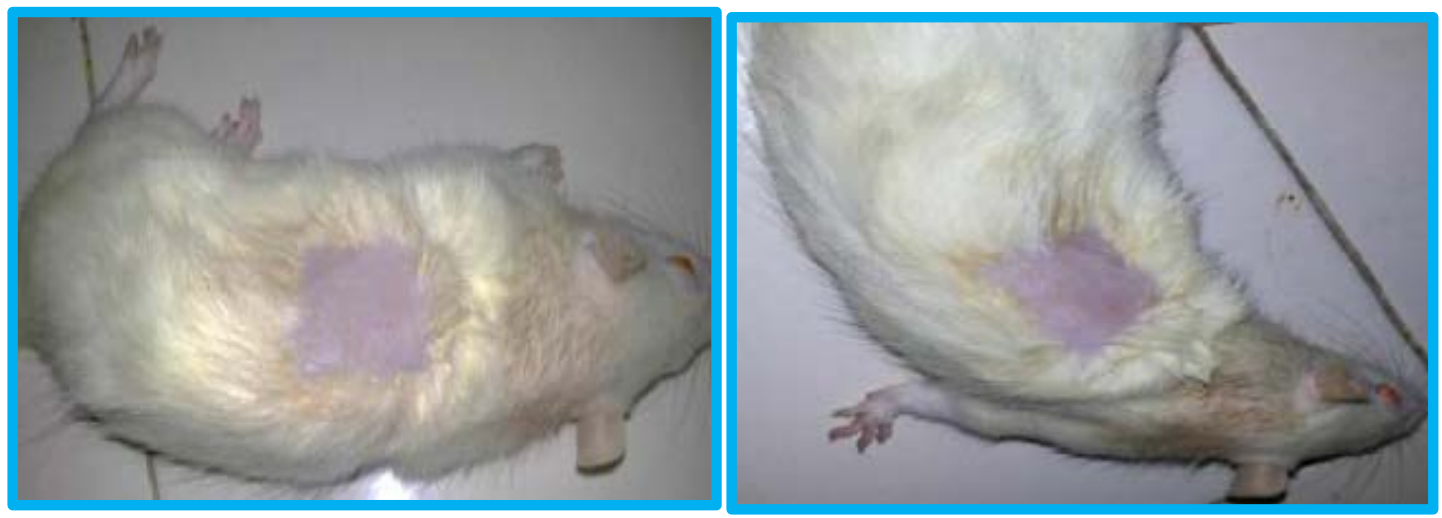

Fig. 9: Before-skin irritation study and after-skin irritation study

Table 13: Stability studies results of optimized batch S9

\begin{tabular}{lllll}
\hline Stability conditions & Sampling time & Folding endurance & Drug content uniformity (\%) & Ex-vivo drug release (\%) \\
\hline Accelerated & Initial $(0 \mathrm{~d})$ & $397 \pm 1.50$ & $98.91 \pm 0.64$ & $94.39 \pm 0.15$ \\
condition & After $15 \mathrm{~d}$ & $384 \pm 2.32$ & $98.85 \pm 0.32$ & $94.31 \pm 0.64$ \\
$\left(40 \pm 2{ }^{\circ} \mathrm{C}\right.$ & After $30 \mathrm{~d}$ & $371 \pm 1.02$ & $98.75 \pm 0.16$ & $94.27 \pm 0.10$ \\
and $75 \pm 5 \% \mathrm{RH})$ & After $90 \mathrm{~d}$ & $369 \pm 2.63$ & $98.69 \pm 0.40$ & $94.20 \pm 0.31$ \\
$($ Batch S9) & After $180 \mathrm{~d}$ & $364 \pm 2.04$ & $98.42 \pm 0.06$ & $94.17 \pm 0.02$ \\
\hline
\end{tabular}




\section{Comparisons with marketed preparation}

Last optimized batch S9 contrasted and compared with marketed formulation, (Daksone) extended-release tablet for drug delivery study. The promoted item and enhanced cluster were exposed to in vitro disintegration concentrate for up to $16 \mathrm{~h}$ utilizing dissolution apparatus II. [51] Optimized transdermal patch exposed to in vitro concentrate with the assistance of glass slide on which wistar rodent skin connect and a patch was stick on the rodent skin [52]. The acquired medication release profile proposed that from the optimized batch S9 drug was constantly discharged through the Wistar rodent skin up to $16 \mathrm{hr}$ and the delivery design was like the in vitro dissolution profile of the market product. This uncovered from the medication stacked transdermal patch constantly releases the drug in a controlled way up to $16 \mathrm{~h}$.

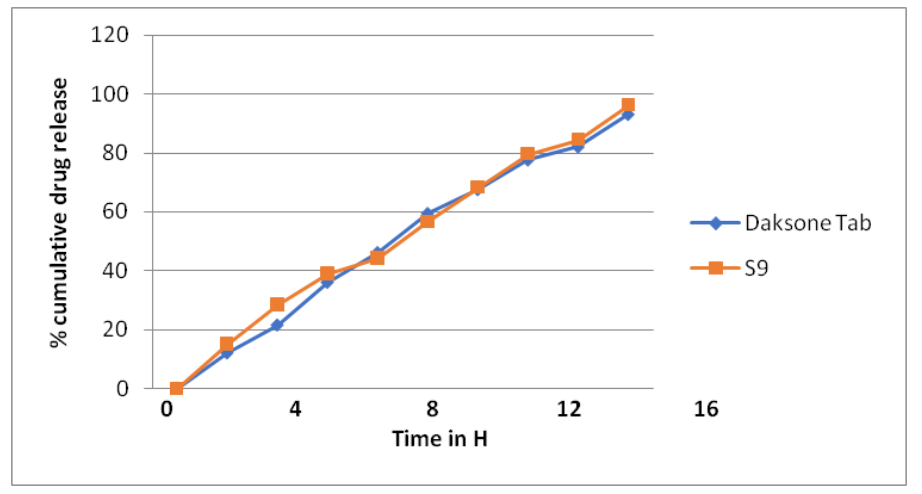

Fig. 10: Comparative drug release of batch $S 9$ and extended-release tablet

Table 14: Calculation of similarity factor for ER tablet (Daksone) and batch S9

\begin{tabular}{|c|c|c|c|c|}
\hline Time (h) & Rt \% CDR ER tablet & Tt \% CDR batch S9 & Rt-Tt & $(\mathrm{Rt}-\mathrm{Tt})^{2}$ \\
\hline 0.5 & 5.76 & 5.51 & 0.25 & 0.0625 \\
\hline 1 & 12.80 & 11.98 & 0.82 & 0.6724 \\
\hline 2 & 29.90 & 28.23 & 1.67 & 2.7889 \\
\hline 3 & 47.62 & 46.15 & 1.47 & 2.1609 \\
\hline 4 & 59.03 & 58.30 & 0.73 & 0.5329 \\
\hline 8 & 70.21 & 69.52 & 0.69 & 0.4761 \\
\hline 12 & 84.36 & 78.75 & 5.61 & 31.4721 \\
\hline \multirow[t]{2}{*}{16} & 93.44 & 89.02 & 4.42 & 19.5364 \\
\hline & & & & $\sum(\mathrm{Rt}-\mathrm{Tt})^{2}(57.7022)$ \\
\hline
\end{tabular}

\section{CONCLUSION}

A regression coefficient $\left(\mathrm{R}^{2}\right)$ at $245 \mathrm{~nm}$ was found to be 0.994 . The Correlation Coefficient $\left(R^{2}\right)=0.993$ and $Y=0.022 x+0.056$ Regression coefficient (R2). This was obvious from the aftereffects of eplerenone permeation at $16 \mathrm{~h}$ from PEC2 to PEC7 with MO thus at various groupings of $10 \% \mathrm{w} / \mathrm{w}$ and $20 \% \mathrm{w} / \mathrm{w}$ of the all-out weight of polymer dry weight. Drug content outcomes were additionally discovered uniform in all clusters in a range of $97 \%$ to $98 \%$. The $e x-$ vivo release likewise proposed that the concentration of SO and PG both had a significant impact on drug release. The correlation coefficient $\left(\mathrm{R}^{2}\right)$ of Higuchi's model was seen as 0.9752 , which shows the diffusion of medication from the readied patches. The determined estimation of eplerenone enhanced batch S9 was seen as 57.70.

\section{ACKNOWLEDGEMENT}

The authors are grateful to VISTAS, Chennai, and Hon. Shri. Babanrao Pachpute Vichardhara Trust's, Parikrama Group of Institutions, Kashti, for providing the required facilities for doing this work.

\section{FUNDING}

Nil

\section{AUTHORS CONTRIBUTIONS}

All the authors have equally contributed to this manuscript.

\section{CONFLICT OF INTERESTS}

The authors declare no conflict of interest, financial or otherwise.

\section{REFERENCES}

1. Oza NA, Sahu AR, Patel DM, Patel PU, Patel LD, Koshia HG. Studies on optimization of the reservoir-type transdermal patch using carvedilol using $3^{2}$ full factorial designs. Int J Res Med. 2013 Sep;2(4):84Ğ89.

2. Brajesh M, Naina K, Shashank S. Quantitative determination of eplerenone in bulk drug and tablet dosage form by TLC/densitometry. Int J Pharm Life Sci. 2011 Jun;2:502-5.

3. Stier CT. Eplerenone: a selective aldosterone blocker. Cardiovasc Drug Rev. 2003 Feb;21(3):169-84. doi: 10.1111/j.1527-3466.2003.tb00114.x, PMID 12931252.

4. Naresh Chandra Reddy M, Chandra Sekhar KB. Development and validation of gradient RP-HPLC for estimation of impurities in eplerenone tablet dosage form. Int Res J Pharm Appl Sci. 2012 Aug;2:58-75.

5. Weinberger MH, Roniker B, Krause SL, Weiss RJ. Eplerenone, a selective aldosterone blocker, in mild-to-moderate hypertension. Am J Hypertens. 2002 Jul;15(8):709-16. doi: 10.1016/s0895-7061(02)02957-6, PMID 12160194.

6. White WB, Duprez D, St Hillaire R, Krause S, Roniker B, KuseHamilton J, Weber MA. Effects of the selective aldosterone blocker eplerenone versus the calcium antagonist amlodipine in systolic hypertension. Hypertension. 2003 Dec;41(5):10216. doi: 10.1161/01.HYP.0000067463.13172.EA, PMID 12682082.

7. Moore TD, Nawarskas JJ, Anderson JR. Eplerenone: a selective aldosterone Receptor antagonist for hypertension and heart failure. Heart Dis. 2003 May;5(5):354-63. doi: 10.1097/01.hdx.0000089783.30450.cb, PMID 14503934.

8. Patel RP, Patel G, Baria A. Formulation and evaluation of transdermal patch of aceclofenac. Int J Drug Del 2009;1(1):4151. doi: 10.5138/ijdd.2009.0975.0215.01005.

9. Das A, Ahmed AB. Formulation and evaluation of transdermal patch of indomethacin containing patchouli oil as a natural penetration enhancer. Asian J Pharm Clin Res. 2017;10(11):320-5. doi: 10.22159/ajpcr.2017.v10i11.20926. 
10. Mishra AD, Khunt DM, Ghayal AH, Patel CN, Shah DR. Formulation and optimization of ethosomes for transdermal delivery of felodipine. Res J Pharm Technol. 2012 May;5(12):1509-17.

11. Mishra AD, Patel CN, Shah DR. Formulation and optimization of ethosomes for transdermal delivery of ropinirole hydrochloride. Curr Drug Deliv. 2013 Oct 1;10(5):500-16. doi: 10.2174/1567201811310050002, PMID 23410071.

12. Rao MR, Sonavane V, Kulkarni S, Magar M, Zope A, Karanjkar P. Design of transdermal patch of ketoprofen by full factorial design for the treatment of rheumatoid arthritis. J Drug Delivery Ther. 2019 Mar 15;9(2):197-205. doi: 10.22270/jddt.v9i2.2549.

13. Lankaranian D, Reis R, Henderer JD, Choe S, Moster MR. Comparison of single thickness and double thickness processed pericardium patch graft in glaucoma drainage device surgery: a single surgeon comparison of outcome. J Glaucoma. 2008 Jan 1;17(1):48-51. doi: 10.1097/IJG.0b013e318133fc49, PMID 18303385.

14. Leo A, Hansch C, Elkins D. Partition coefficients and their uses. Chem Rev. 1971;71(6):525-616. doi: 10.1021/cr60274a001.

15. Nichols L. Step-by-step procedures for melting point determination. Chemistry Libre Text 2021.

16. Jamakandi VG, Mulla JS, Vinay BL, Shivakumar HN. Formulation, characterization, and evaluation of matrix-type transdermal patches of a model antihypertensive drug. Asian J Pharm. 2009;3(1). doi: 10.4103/0973-8398.49177.

17. Guyot M, Fawaz F. Design and in vitro evaluation of adhesive matrix for transdermal delivery of propranolol. Int J Pharm. 2000 Jun 20;204(1-2):171-82. doi: 10.1016/s03785173(00)00494-4, PMID 11012001.

18. Wang J, Ruan J, Zhang C, Ye Y, Cai Y, Wu Y. Development and evaluation of the sinomenine transdermal patch. Pak J Pharm Sci. 2008 Oct 1;21(4):407-10. PMID 18930863.

19. Aggarwal G, Dhawan S, Harikumar SL. Formulation, in vitro, and in vivo evaluation of matrix-type transdermal patches containing olanzapine. Pharm Dev Technol. 2013 Aug 1;18(4):916-25. doi: 10.3109/10837450.2011.609993, PMID 21913873.

20. Parivesh S, Sumeet D, Abhishek D. Design, evaluation, parameters and marketed products of transdermal patches: a review. J Pharm Res. 2010 Feb;3(2):235-40.

21. Gaikwad KA. Transdermal drug delivery system: formulation aspects and evaluation. Int J PharmTech Res. 2013 Mar;3(4):2140-8.

22. Darwhekar G, Jain DK, Patidar VK. Formulation and evaluation of transdermal drug delivery system of clopidogrel bisulphate. Asian J Pharm Life Sci. 2011 Jan;1(3):14-20.

23. Latheeshjlal LP, Phanitejaswini SY, Swapna U, Sarika V, Moulika G. Transdermal drug delivery systems: an overview. Int J Pharmtechn Res. 2011 Mar;3(4):1-8.

24. Kumar SR, Jain A, Nayak S. Development and evaluation of transdermal patches of colchicine. Pharm Lett. 2012 Apr;4(1):330-43.

25. Mutalik S, Udupa N. Glibenclamide transdermal patches: physicochemical, pharmacodynamic, and pharmacokinetic evaluations. J Pharm Sci. 2004 Jun;93(6):1577-94. doi: 10.1002/jps.20058, PMID 15124215.

26. Mali AD, Bathe R, Patil M. An updated review on transdermal drug delivery systems. Int J Adv Sci Res. 2015 Jan;1(6):244-54. doi: 10.7439/ijasr.v1i6.2243.

27. Bagchi A, Dey BK. Formulation, in vitro evaluations and skin irritation study of losartan potassium transdermal patches. Iran J Pharm Sci. 2010 Jun;6(3):163-70.

28. Keleb E, Sharma R, Mosa EB, Zaljahwi AZ. Transdermal drug delivery system design and evaluation. Int J Adv Pharm Sci. 2010 Feb;1:201-11.

29. Prajapati ST, Patel CG, Patel CN. Formulation and evaluation of transdermal patch of repaglinide. ISRN Pharm. 2011;2011:651909. doi: 10.5402/2011/651909, PMID 22389856.

30. Kavitha K, Rajendra MM. Design and evaluation of transdermal films of lornoxicam. Int J Pharm Biol Sci. 2011 Jun 30;2(2):5462.

31. Furuishi T, Io T, Fukami T, Suzuki T, Tomono K. Formulation and in vitro evaluation of pentazocine transdermal delivery system. Biol Pharm Bull. 2008 Jul 1;31(7):1439-43.
32. Gutschke E, Bracht S, Nagel S, Weitschies W. Adhesion testing of transdermal matrix patches with a probe tack test-in vitro and in vivo evaluation. Eur J Pharm Biopharm. 2010 Aug 1;75(3):399-404. doi: 10.1016/j.ejpb.2010.03.016, PMID 20350598.

33. Saroha K, Yadav B, Sharma B. Transdermal patch: A discrete dosage form. Int J Curr Pharm Res. 2011 Apr;3(3):98-108.

34. Ravikumar R, Ganesh M, Senthil V, Ramesh YV, Jakki SL, Choi EY. Tetrahydro curcumin loaded PCL-PEG electrospun transdermal nanofiber patch: preparation, characterization, and in vitro diffusion evaluations. J Drug Deliv Sci Technol. 2018 Apr 1;44:342-8. doi: 10.1016/j.jddst.2018.01.016.

35. Pongjanyakul T, Prakongpan S, Priprem A. Acrylic matrix type nicotine transdermal patches: in vitro evaluations and batch-tobatch uniformity. Drug Dev Ind Pharm. 2003 Jan 1;29(8):84353. doi: $10.1081 /$ ddc-120024180, PMID 14570305.

36. Jayakumar C, Kumar KD, Nesakumar D, Gandhi NN. Quantitative analysis of theophylline bulk sample using sodium salicylate hydrotrope. Int J Pharm Pharm Sci 2010;2(3):124-5.

37. Sharma S, Aggarwal G, Dhawan S. Design and evaluation of olanzapine transdermal patches containing vegetable oils as permeation enhancers. Scholars Research Library. 2010 Feb;2(6):84-98.

38. Gannu R, Vishnu YV, Kishan V, Rao YM. Development of nitrendipine transdermal patches: in vitro and ex vivo characterization. Curr Drug Deliv. 2007 Jan 1;4(1):69-76. doi: 10.2174/156720107779314767, PMID 17269919.

39. Pathan BI, Setty CM, Gupta VRM. Comparison of the effect of essential oils on the permeation of diclofenac diethylamine through various barriers. Acta Pharm Sci. 2008 Aug;50(3):21928.

40. Marwah H, Garg T, Goyal AK, Rath G. Permeation enhancer strategies in transdermal drug delivery. Drug Deliv. 2016;23(2):564-78. doi: 10.3109/10717544.2014.935532, PMID 25006687.

41. Kunta JR, Goskonda VR, Brotherton HO, Khan MA, Reddy IK. Effect of menthol and related terpenes on the percutaneous absorption of propranolol across excised hairless mouse skin. J Pharm Sci. 1997 Nov;86(12):1369-73. doi: 10.1021/js970161+, PMID 9423148.

42. Pfister WR, Hsieh DS. Permeation enhancers compatible with transdermal drug delivery systems. Part I: selection and formulation considerations. Med Dev Technol. 1990 Dec;1(5):48-55. PMID 10171148.

43. Pfister WR, Hsieh DS. Permeation enhancers compatible with transdermal drug delivery systems: part II: system design considerations. Med Dev Technol. 1990 Jul;1(6):28-33. PMID 10171149.

44. Norton BJ, Strube MJ. Guide for the interpretation of the twoway analysis of variance. Phys Ther. 1986 Apr;66(3):402-12. doi: 10.1093/ptj/66.3.402, PMID 3952157.

45. Kim HY. Statistical notes for clinical researchers: two-way analysis of variance (ANOVA)-exploring possible interaction between factors. Restor Dent Endod. 2014 Feb;39(2):143-7. doi: 10.5395/rde.2014.39.2.143, PMID 24790929.

46. Banerjee S, Chattopadhyay P, Ghosh A, Pathak MP, Singh S, Veer V. Acute dermal irritation, sensitization, and acute toxicity studies of a transdermal patch for prophylaxis against $(\{+/-\})$ anatoxin-a poisoning. Int J Toxicol. $2013 \mathrm{Apr} ; 32$ (4):308-13. doi: 10.1177/1091581813489996, PMID 23696561.

47. Kawahara K, Tojo K. Skin irritation in transdermal drug delivery systems: a strategy for its reduction. Pharm Res. 2007;24(2):399-408. doi: 10.1007/s11095-006-9165-4, PMID 17191093.

48. Vishwakarma AK, Panda P, Verma NK, Vishwakarma DK, Mishra JN. An overview of transdermal patches. Int J Pharm Rev Res. 2017;7(1):17-23.

49. Shinde AJ, Shinde AL, More HN. Design and evaluation of transdermal drug delivery system of gliclazide. Asian J Pharm. 2010 Feb;4(2):121-9. doi: 10.4103/0973-8398.68463.

50. Trivedi D, Goyal A. Formulation and evaluation of transdermal patches containing dexketoprofen trometamol. Int J Pharm Chem Anal. 2020 Oct;7(2):87-97. doi: 10.18231/ j.ijpca.2020.014. 
51. Deepika B, Juveria T, Kandukoori NR, Sarojini S, Sowmya S. Dissolution: A predictive tool for conventional and novel dosage forms. J Pharm Res. 2018 Nov;7(6):113-9.
52. Khan $\mathrm{R}$, Irchhaiya R. In vitro in vivo evaluation of niosomal formulation of famotidine. Int J Pharm Pharm Sci. 2020 Jan 10:15-22. doi: 10.22159/ijpps.2020v12i3.36210. 